УДК 351:614.4

DOI https://doi.org/10.32837/pyuv.v0i5(34).656

\author{
В. М. Зальотін \\ orcid.org/0000-0002-4630-1947 \\ аспірант кафедри нотаріального, виконавчого процесу та адвокатури, прокуратури, судоустрою \\ Інституту права \\ Київського національного університету ілені Тараса Шевченка \\ Я.С. Бабич \\ orcid.org/0000-0002-3616-5515 \\ аспірант кафедри службового та ледичного права \\ Інституту права \\ Київського національного університету ілені Тараса Шевченка
}

\title{
ПЕРЕХІД ДО Е-НОТАРІАТУ ЯК ПРОТИЕПІДЕМІЧНИЙ ЗАХІД ДЕРЖАВИ
}

Постановка проблеми. На думку відомого математика та трейдера Нассіма Талеба, люди схильні помічати лише ті проблеми, від яких не були захищені заздалегідь. Натомість запроваджені запобіжні заходи ніхто не помічає, адже не відчуває на собі вплив проблем, від яких вони захищають. Можливо, саме тому велика кількість законів приймається вже після того, як виявляються проблеми їх відсутності [1].

Так сталося і під час розповсюдження гострої респіраторної хвороби COVID-19, спричиненої коронавірусом SARS-CoV-2 (далі - «COVID-19»). Світ переважно був не готовий до такого розвитку подій, і більшість держав вимушено переглянула своє протиепідемічне законодавство. У таких умовах змінилися і підходи країн до застосування сучасних технологій у суспільстві. Зумовлений COVID-19 перехід ряду країн до е-нотаріату можна розглядати як один із протиепідемічних заходів.

Стан дослідження. Протиепідемічні заходи держави в українській науці досліджувалися переважно з медичної сторони. Правовий аспект протидії держави інфекційним захворюванням досліджувався такими вітчизняними науковцями, як Н.О. Васюк, З.С. Гладун, М.П. Ліхтер, В.Г. Чорна, В.В. Шафранський тощо. Крім того, е-врядування загалом та е-нотаріат зокрема не розглядалися як протиепідемічні заходи держави. Е-нотаріат у своїх розвідках так чи інакше аналізували такі дослідники, як О.Ю. Кузьмінська, Х.М. Маркович, В.М. Марченко, Н.М. Павлюк, В.В. Приловський та багато інших. Водночас вплив зовнішніх чинників (таких як інфекційні захворювання) на запровадження е-нотаріату не досліджувався.

Метою дослідження є виокремлення переходу до е-нотаріату як протиепідемічного заходу держави та вивчення міжнародного досвіду запровадження е-нотаріату для можливості його застосування в Україні.

Виклад основного матеріалу. Останнім викликом сьогодення як для України, так і для всього світу стало стрімке поширення COVID-19. Відповідно до ст. 30 Закону України «Основи законодавства України про охорону здоров'я» від 19.11.1992 р. № 2801-XII держава забезпечує планомірне науково обгрунтоване попередження, лікування, локалізацію та ліквідацію масових інфекційних захворювань [2].

Варто погодитися із думкою української дослідниці Е.Н. Орінди, яка вказує на те, що дезінформація, недостатність національних ресурсів епідеміологічного нагляду і засобів стримування епідемій, а також відсутність міжнародного механізму надання допомоги, як в юридичній, так і в практичній формі, може сприяти тому, що спалах епідемії набуде характеру загрози міжнародного масштабу [3, с. 199].

Слід зазначити, що для подолання пандемії гостро необхідне ефективне управління у сфері охорони здоров'я, яке включає в себе належне забезпечення державою протиепідемічних заходів. Визначення терміну «протиепідемічні заходи держави» міститься у Законі України «Про захист населення від інфекційних хвороб" від 06.04 .2000 p. № 1645-III [4]. Це поняття включає в себе комплекс організаційних, медико-санітарних, ветеринарних, інженерно-технічних, адміністративних та інших заходів, що здійснюються з метою запобігання поширенню інфекційних хвороб, локалізації та ліквідації їх осередків, спалахів та епідемій. Таким чином, можемо констатувати, що наведені заходи є загальними та невичерпними, що своєю чергу потребує подальшого законодавчого роз'яснення та водночас дає простір для розробки нових протиепідемічних заходів держави.

Кандидат медичних наук О.В. Рябоконь наголошує на тому, що протиепідемічні заходи мають бути спрямовані на нейтралізацію джерел інфекції, розрив шляхів і механізмів передачі збудників, підвищення несприйнятливості населення до інфекційних захворювань, послаблення дії на людей різних екстремальних чинників [5, с. 16-17]. 
3 огляду на вищезазначене ми вважаємо, що запровадження е-нотаріату як складника е-врядування із застосуванням технологій електронного документообігу та ідентифікації особи в умовах пандемії COVID-19 може вважатися одним із протиепідемічних заходів держави. Особливість цього протиепідемічного заходу полягає у можливості його подальшого існування як частини національного законодавства навіть після того, як хвороба буде приборкана.

Отже, визначившись 3 таким протиепідемічним заходом, розкриємо його технологічні підвалини, а саме електронний документообіг та ідентифікацію особи у правовідносинах з електронним документообігом.

Запровадження електронного документообігу не було пов'язано із епідеміологічною ситуацією в країні, оскільки почалося задовго до появи COVID-19. Закон України «Про електронні документи та електронний документообіг» від 22.05.2003 р. № 851-IV [6] заклав фундамент для подальшого розвитку електронної держави.

Н.О. Левицька доцільно зауважує, що система зовнішнього документообігу, у якому доступ до юридичних документів наявний у будь-який час та у будь-якому місці, набирає обертів. Перехід на безпаперове діловодство зменшить витрати, а інформація розміщується в більш доступному для управління та спільної роботи місці $[7$, с. 63].

Ключовим питанням електронного документообігу є ідентифікація осіб, що ознайомлюються 3 документами, вносять до системи нові документи або зміни до них. Сьогодні це питання регулюється Законом України «Про електронні довірчі послуги» від 05.10.2017 р. № 2155-VIII [8]. Законодавці передбачили три види електронних підписів, кожному з яких притаманна власна технологія шифрування даних:

- простий електронний підпис та печатка;

- удосконалений електронний підпис та печатка;

- кваліфікований електронний підпис та печатка.

Лише останній прирівнюється до власноручного підпису особи. Кваліфікований електронний підпис (далі - КЕП) зберігається на спеціальному носіі інформації у формі USB-флеш-накопичувача та видається конкретній особі. Для отримання власного кваліфікованого електронного підпису треба надати копії документа, що встановлюе особу, та ідентифікаційного номеру облікової картки платника податків. Використати КЕП можна під час введення паролю, який має знати лише його власник. Наразі використання КЕП є обов'язковим для посадових осіб органів державної влади та місцевого самоврядування, реєстраторів, нотаріусів тощо. За два роки свого існування така система ідентифікації показала свою ефективність і може бути основою для впровадження е-нотаріату в Україні.
Також маємо відмітити, що е-нотаріат безумовно є складником е-врядування, адже заснований на взаємодії державних реєстрів та інформаційнокомунікаційних ресурсів. Відтак без комплексного застосування технологій у функціонуванні держави е-нотаріат неможливий.

Відповідно до Кембриджського словника «е-врядування», або ж «електронне врядування», - це використання урядом Інтернету з метою надання людям можливості отримувати державні послуги та брати участь у прийнятті рішень [9].

Традиційно та небезпідставно взірцем е-врядування вважають Естонію, яка поступово розвивалася у відповідному напрямі з 2000 року. Наразі замість паспорта кожен естонець з 15 років отримує спеціальну ID-картку. Завдяки програмі X-Road забезпечується взаємозв'язок між реєстрами і через таку картку можна отримувати практично усі державні послуги [10].

Варто зазначити, що останнім часом Україна сприяє розвитку е-врядування доволі інтенсивно. Зокрема, наразі існує можливість пройти весь шлях від подання позовної заяви до примусового виконання рішення суду виключно через державні інформаційно-комунікаційні системи. Завдяки Єдиним державним веб-порталам електронних послуг «Онлайн будинок юстиції» [11] та «Дія» [12] з'явилась можливість дистанційно реєструвати фізичних осіб-підприємців та юридичних осіб, отримувати відомості 3 державних реєстрів, отримувати ліцензії та дозволи, реєструвати транспортні засоби, акти цивільного стану тощо. 3 початку 2020 р. запроваджений мобільний додаток «Дія», в якому документи, що посвідчують особу (ID-паспорт та посвідчення водія), прирівнюються до паперових оригіналів.

Крім того, на державному та регіональному рівнях є можливості відслідковувати штрафи за порушення правил дорожнього руху, евакуацію транспортного засобу, подавати електронні петиції тощо.

Попри такий стрімкий розвиток електронного врядування - в Україні е-нотаріат досі відсутній. Ще у лютому 2020 року міністр юстиції Д.Л. Малюська повідомив, що у міністерстві розробили законопроєкт, який надасть нотаріусам можливість завіряти електронні документи [13]. На жаль, у Верховній Раді цей законопроєкт досі не зареєстрований.

Попри зацікавленість вітчизняних науковців у е-нотаріаті, його визначення досі не сформоване ні на законодавчому, ні на доктринальному рівнях. Як вдало зазначив В.В. Приловський, «це поки що абстрактне визначення окремої ланки нотаріальної діяльності» [14, с. 130]. У закордонних джерелах знаходимо визначення «е-нотаріуса» (eNotary) - нотаріуса, який вчиняє нотаріальні дії електронно (віддалено) із застосуванням електронного підпису [15]. 
На нашу думку, е-нотаріат можна визначити як забезпечену державою можливість віддаленого вчинення нотаріальних дій при ідентифікації усіх iii учасників та завдяки функціонуванню державних інформаційно-комунікаційних систем.

Протиепідемічні заходи у сфері вчинення нотаріальних дій зводяться лише до особливих правил роботи нотаріусів. Відповідно до листа Міністерства юстиції України «Щодо організації роботи державних нотаріальних контор та приватних нотаріусів на час дії карантину» від 17.03.2020 р. нотаріусам рекомендується обмежити прийом громадян (лише для невідкладних нотаріальних дій) та здійснювати усі можливі профілактичні заходи для боротьби з хворобою. Віддаленим понині $€$ тільки консультування громадян [16].

Водночас досвід іноземних країн демонструє позитивну практику запровадження е-нотаріату.

Відповідно до 10 принципу Принципів подолання кризи COVID-19 Європейського інституту права держави повинні забезпечити можливість укладання контрактів, прийняття управлінських рішень та здійснення всіх інших юридично значущих дій на відстані, включаючи вчинення нотаріальних дій [17]. Як ми пересвідчимось далі, окремі країни Європи та світу намагаються дотримуватися цього принципу.

30.04.2020 р. у Бельгії було прийнято Закон «Про різні положення про правосуддя та нотаріальну роботу в контексті боротьби з поширенням COVID-19». Запроваджено зміни до законодавства, що регламентує діяльність нотаріусів. Зокрема, ст. 11 згаданого Закону тимчасово зупинено положення щодо необхідності залучення нотаріусом двох свідків у разі, коли одна зі сторін не може підписатись, сліпа або глухоніма. Крім того, ст. 6 Закону допускає вчинення нотаріальних дій віддалено. У зв'язку з необхідністю ідентифікації сторін Закон вимагає, щоб сторони зв'язувалися з нотаріусом у режимі відеоконференції та використовували один із двох методів для ідентифікації:

- бельгійська електронна ідентифікаційна карта або “еID” - доступна резидентам Бельгії (незалежно від громадянства) та бельгійським громадянам за кордоном;

- itsme, мобільний додаток, який діє виключно в Бельгії.

Пар. 6 ст. 6 Закону при цьому вказує, що положення про територіальну компетенцію нотаріуса під час вчинення нотаріальних дій віддалено не застосовуються [18].

COVID-19 став причиною запровадження е-нотаріату у Бразилії. Міністерство юстиції прийняло постанову № 100 від 25.05.2020 р., відповідно до якої доступ до електронного нотаріату здійснюється з використанням цифрового підпису або за допомогою біометричних технологій (наприклад, у пар. 3 ст. 18 зазначається відбиток пальця). Проте для нотаріусів встановлені критерії територіальної компетенції:

- якщо в межах однієї віддаленої нотаріальної дії фігурують об'єкти нерухомого майна, що знаходяться в різних областях, вчиняти нотаріальну дію може нотаріус за місцем реєстрації будь-якого з об'єктів нерухомого майна (пар. 1 ст. 19);

- якщо нерухоме майно знаходиться в державі проживання покупця, нотаріальну дію можна вчиняти у нотаріуса держави проживання покупця (пар. 2 ст. 19);

- інші нотаріальні дії вчиняються нотаріусом за місцем проведення реєстраційної діі;

- якщо внаслідок вчинення нотаріальної дії у реєстри зміни не вносяться - нотаріальні дії вчиняються за місцем проживання заявника (ст. 20) [19].

Перспектива впровадження електронного нотаріату наразі розглядається у Сполучених Штатах Америки. 18.03.2020 р. до парламенту було подано законопроєкт № 3533 (Закон про захист і підтримку торгівлі з використанням дистанційного та електронного нотаріального завірення), яким запропоновано дозволити віддалене вчинення нотаріальних дій [20]. Відмітимо, що електронний нотаріат діє на рівні окремих штатів. Станом на 12.11 .2020 p. вже у 29 штатах із 50 легалізоване віддалене вчинення нотаріальних дій [21].

Повністю відмовитись від паперового документообігу у нотаріаті поки що не можуть на Філіппінах. Відповідно до Тимчасових правил дистанційного нотаріального завірення паперових документів AM № 20-07-04-СК документи можуть бути доставлені нотаріусу в запечатаному пакеті особисто або кур'єром. Національне законодавство вимагає, щоб в такому пакеті знаходився компакт-диск (CD) або флеш-накопичувач (USB), який містить відео підписання особою документа (відео також можна надіслати електронною поштою або іншими цифровими засобами зв'язку). Якщо особа, що звертається за вчиненням нотаріальної дії, нотаріусу невідома, необхідно також відправити 2 копії виданих державою посвідчень особи. Така ж вимога розповсюджується і на свідків [22].

Відзначимо той факт, що в деяких країнах електронний нотаріат запроваджено ще до розповсюдження COVID-19, проте у зв'язку із епідемією він зазнав певних змін.

Зокрема, в Австрії е-нотаріат запроваджено у 2018 році [23]. Водночас ст. 34 Федерального закону від 04.04.2020 р. дозволено вчиняти нотаріальні дії віддалено не лише у разі відсутності однієї зі сторін правочину у нотаріуса, але й за бажанням сторін загалом [24].

Розкриваючи тему електронного нотаріату, не можна не згадати передову країну в означеному 
питанні - Естонію. Пар. 44-1 Закону Естонії «Про нотаріат» у 2007 р. запроваджено електронну інформаційну систему нотаріусів (е-нотаріат). Це стало можливим завдяки двом ключовим положенням:

- усе діловодство нотаріуса зберігається у електронному вигляді (п. 1-2 пар. 16).

- нотаріальні дії можуть вчинятися віддалено під час ідентифікації усіх учасників такої нотаріальної дії (п. 5-1 пар. 36) [25].

Відмітимо, що з 06.04.2020 p. усі без винятку нотаріальні дії (без іноземного елементу) стало можливим вчиняти віддалено (п. 6-1 пар. 12 Нотаріальних правил Естоніі) [26]. Е-нотаріат так і не став би реальністю, якби в Естонії не впровадили електронне врядування, про яке ми вже писали вище.

Отже, COVID-19 можна вважати стимулюючим фактором, завдяки якому поповнюється список держав з е-нотаріатом. Позитивним є те, що у цих країнах електронний нотаріат продовжить своє існування навіть після перемоги над хворобою.

Висновки. Таким чином, варто констатувати, що наша країна не була готова до викликів пандемії. Поняття протиепідемічних заходів хоч і міститься в Законі України «Про інфекційні хвороби", проте має загальний та невичерпний характер. Вважаємо за доцільне звернути особливу увагу саме на ті, які дозволяють використовувати досягнення науково-технічного прогресу сьогодення. 3 огляду на проведене дослідження необхідність е-нотаріату (навіть без ризику розповсюдження інфекційних хвороб) не викликає жодних сумнівів. Економія часу та матеріальних ресурсів у довгостроковій перспективі очевидно сприятимуть розвитку держави та її громадян. Враховуючи світовий досвід та розвинене е-врядування в Україні, варто запровадити віддалене вчинення нотаріальних дій. Це стане можливим завдяки:

1. Ідентифікації учасників нотаріальних дій із застосуванням кваліфікованих електронних підписів та відеозв'язку;

2. Дистанційному доступу учасників нотаріальних дій до усіх необхідних реєстрів;

3. Повністю електронному діловодству нотаріусів.

Завдяки е-нотаріату з'являються можливості убезпечити громадян від зайвих контактів, а відтак вплинути на зменшення кількості захворюваності. Переконані, що перехід на е-нотаріат є ефективним протиепідемічним заходом, який поступово має впроваджуватися в Україні.

\section{Jimepamypa}

1. Черный лебедь. Под знаком непредсказуемости. 2-е изд. доп. / Нассим Николас Талеб : Пер. с англ. Москва : КоЛибри, Азбука-Аттикус, 2012. 736 с.
2. Основи законодавства України про охорону здоров'я: Закон України від 19.11.1992 № 2801-XII. URL: https://zakon.rada.gov.ua/laws/show/280112\#Text

3. Орінда Е.Н. Міжнародно-правове співробітництво у боротьбі з розповсюдженням інфекційних захворювань в Африці. Вісник Південного регіонального иентру Національної акаделї̈ правових наук України. 2016. № 8. с. 198-202.

4. Про захист населення від інфекційних хвороб: Закон України від 06.04.2000 р. № 1645-III. URL: https://zakon.rada.gov.ua/laws/show/164514\#Text.

5. Рябоконь О.В. Особливості проведення протиепідемічних заходів у випадках виникнення надзвичайних ситуацій в мирний час за умов занесення карантинних інфекцій. Протиепідемічний захист військ, бактеріологічна розвідка : навч. посіб. для студентів V курсу мед. ф-ту / О.В. Рябоконь, Т.Є. Оніщенко, Б.Г. Тютюнщиков. Запоріжжя : [ЗДМУ], 2016. 107 с.

6. Про електронні документи та електронний документообіг: Закон України від 22.05.2003 № 851-IV. URL: https://zakon.rada.gov.ua/laws/show/ 851-15\#Text.

7. Левицька Н.О. Цифрова трансформація в юридичній діяльності. Міжнародний науковий журнал «Інтернаука». Серія: «Юридичні науки». 2020. №7 (29). C. 61-67.

8. Про електронні довірчі послуги: Закон України від 05.10.2017 № 2155-VIII. URL: https://zakon. rada.gov.ua/laws/show/2155-19\#text.

9. Визначення E-GOVERNANCE у кембриджському словнику англійської мови. URL: https://dictionary.cambridge.org/ru/ru/словарь/ английский/e-governance

10. E-Estonia. URL: https://e-estonia.com.

11. Он-лайн будинок юстиції. URL: https://online.minjust.gov.ua.

12. Єдиний портал державних послуг «ДІЯ». URL: https://diia.gov.ua.

13. Денис Малюська: електронна система нотаріату може бути запущена до кінця 2020 року. URL: https://minjust.gov.ua/news/ministry/denismalyuska-elektronna-sistema-notariatu-moje-butizapuschena-do-kintsya-2020-roku.

14. Приловський В.В. Сучасні проблемні питання нотаріату в Україні / В.В. Приловський. Правова держава: історія, сучасність та перспективи формування в Україні : матер. Всеукр. наук.-практ. конф. (м. Дніпро, 23 лютого 2018 р.). Дніпро : ДДУВС, 2018. С. 130-133.

15. Piombino, Alfred E. (2011). Notary Public Handbook: Principles, Practices \& Cases, National Edition (First ed.). East Coast Publishing. ISBN 978-0-9445606-9-3.

16. Щодо організації роботи державних нотаріальних контор та приватних нотаріусів на час дії карантину: лист Міністерства юстиції України Начальникам міжрегіональних управлінь Міністерства юстиції № 1534/19.5/32-20 від $17.03 .2020 \mathrm{p}$. URL: https://psjust.gov.ua/wp-content/uploads / 2020/03/1584457513999916.pdf.pdf.

17. ELI principles for the COVID-19 crisis. URL: https://www.europeanlawinstitute.eu/fileadmin/ user_upload/p_eli/Publications/ELI_Principles_for_ the $\bar{C}$ OVID-19 Crisis.pdf.

18. Loi portant des dispositions diverses en matiore de justice e de notariat dans le cadre de la lutte contre la propagation du coronavirus COVID-19 (30 avril 2020). URL: http://www.ejustice.just.fgov.be/cgi loi/change lg.pl?language $=$ fr\&la $=F \& c n=2020043003 \& t a b$ 
19. Provimento No 100, De 26 De Maio De 2020 (Conselho Nacional de Justia) Dispoe sobre a protica de atos notariais eletronicos utilizando 0 sistema e-Notariado, cria a Matrocula Notarial Eletronica-MNE e do outras providoncias. URL: https://atos.cnj.jus.br/ atos/detalhar/3334.

20. S.3533 - Securing and Enabling Commerce Using Remote and Electronic Notarization Act of 2020. URL: https://www.congress.gov/bill/116th-congress/ senate-bill $/ 3533$ ? $q=\% 7 \mathrm{~B} \% 22$ search $\% 22 \% 3 \mathrm{~A} \% 5 \mathrm{~B} \% 22$ $3533 \% 22 \% 5 \mathrm{D} \% 7 \mathrm{D} \& \mathrm{~s}=2 \& \mathrm{r}=4$.

21. Coronavirus: Federal and state governments work quickly to enable remote online notarization to meet global crisis. 12 November 2020// Margo H. K. Tank, David Whitaker, Elizabeth S. M. (Liz) Caires, Andrew Grant. URL: https://www.dlapiper.com/en/us/insights/ publications / 2020/03/coronavirus-federal-and-stategovernments-work-quickly-to-enable-remote-onlinenotarization.

22. 2020 Interim Rules on Remote Notarization of Paper Documents A.M. No. 20-07-04-SC, Supreme Court of the Philippines. URL: https://sc.judiciary.gov.ph/ $12490 /$.

23. Die Notariatsordnung, RGBl. Nr. 75/1871, zuletzt geondert durch das Bundesgesetz BGBl. I Nr. 19/2020. URL: https://www.ris.bka.gv.at/ GeltendeFassung.wxe?Abfrage=Bundesnormen\&Gesetz esnummer $=10001677$.

24. Bundesgesetzblatt For Die Republik osterreich COVID-19-Gesetz (NR: GP XXVII IA 403/A AB 116 S. 22. BR: AB 10292 S. 905.). URL: https://www.ris.bka.gv.at/Dokumente/BgblAuth/ BGBLA 2020 I 24/BGBLA 2020 I 24.html.

25. Notariāadiseadus vastu v etud 06.12.2000 RT I 2000, 104, 684. URL: https://www.riigiteataja.ee/ akt/110032016004.

26. Notariaadim rustik vastu voetud 19.06.2009 nr 23 RTL 2009, 51, 751. URL: https://www.riigiteataja.ee/ akt/103042020020?dbNotReadOnly=true.

\section{Анотація}

Зальотін В. М., Бабич Я. С. Перехід до е-нотаріату як протиепідемічний захід держави. - Стаття.

Дослідження присвячено впливу інфекційної хвороби COVID-19 на функціонування нотаріату в Україні та світі. Охарактеризовано законодавче регламентування протидії держави інфекційним захворюванням за законодавством України. Враховуючи невичерпність протиепідемічних заходів держави на рівні законодавства, доведено, що запровадження е-нотаріату можна розглядати як один із протиепідемічних заходів держави. Виокремлено особливість електронного нотаріату як протиепідемічного заходу - після перемоги над хворобою е-нотаріат не потребує скасування. Констатовано, що е-нотаріат є частиною е-врядування, адже заснований на взаємодії державних реєстрів та інформаційно-комунікаційних ресурсів. Розкрито технологічні складники електронного врядування та електронного нотаріату за законодавством України, а саме електронний документообіг та ідентифікацію особи у правовідносинах 3 електронним документообігом. Розглянуто сучасний стан е-врядування в Україні та зроблено висновок про готовність України до запровадження е-нотаріату. Надано визначення е-нотаріату як забезпеченої державою можливості віддаленого вчинення нотаріальних дій під час ідентифікації усіх її учасників та завдяки функціонуванню державних інформаційно-комунікаційних систем. Згадано регламентування роботи нотаріату в умовах розповсюдження COVID-19 в Україні та констатовано його недостатність. Розкрито іноземний досвід застосування протиепідемічних заходів державами у зв'язку із розповсюдженням COVID-19: внесення змін у законодавство, що регулює функціонування нотаріату (Філіппіни, Австрія, Естонія), або ж запровадження електронного нотаріату загалом (Бельгія, Бразилія, Сполучені Штати Америки). Зроблено висновок про необхідність запровадження електронного нотаріату як протиепідемічного заходу в Україні та невіддільного складника електронного врядування загалом. Виокремлено такі обов'язкові елементи майбутнього українського е-нотаріату, як: ідентифікація учасників нотаріальних дій із застосуванням кваліфікованих електронних підписів та відеозв'язку; віддалений доступ учасників нотаріальних дій до усіх необхідних реєстрів; повністю електронне діловодство нотаріусів.

Ключові слова: протиепідемічний захід держави, е-врядування, е-нотаріат, електронний документообіг, ідентифікація особи.

\section{Summary}

Zalyotin V.M., Babych Ya.S. Transfer to e-notary as the state anti-pandemic measure. - Article.

The study is focused on the impact of infectious disease COVID-19 on the functioning of the notary in Ukraine and worldwide. Legislative regulation as the state's contraction against COVID-19 is analyzed. Considering the inexhaustibility of the state anti-pandemic measures at the legislation level, it is proved that the implementation of e-notary can be treated as one of the functional anti-pandemic state measures. The peculiarity of electronic notary as an anti-pandemic state measure is highlighted: after overcoming the consequences of COVID-19, e-notary does not need to be abolished. It is stated that e-notary is an essential part of e-government, because it is based on the interaction between state registers and information/ communication resources.

The technological elements of e-government and e-notary according to the legislation of Ukraine are revealed, namely electronic document circulation and personal electronic identification in the context of electronic document management. The current state of e-government in Ukraine is considered and a conclusion about Ukraine's readiness for e-notary's introduction is made. The definition of e-notary as a state-provided opportunity to remotely perform notarial acts in the identification of all its participants due to the functioning of state information and communication systems is proposed. The regulation of the notary's work in COVID-19 pandemic conditions in Ukraine is mentioned and its insufficiency is stated.

Foreign experience considering the implementation of states' anti-pandemic measures because of COVID-19 is highlighted: amendments to the legislation governing the operation of notaries (Philippines, Austria, Estonia) or the introduction of electronic notaries in general (Belgium, Brazil, United States). It is concluded that there is a strong need to introduce e-notary as an anti-pandemic measure in Ukraine and an integral part of e-government in general. Mandatory elements of the potential Ukrainian e-notary such as: identification of participants in notarial actions with the use of qualified electronic signatures and video communication; remote access of participants of notarial actions to all necessary registers; full electronic record are described.

Key words: anti-pandemic measure of the state, e-government, e-notary, electronic document circulation, personal identification. 